\title{
The Battle of Knockanure
}

\section{Author(s): C. Hussey}

Source: Kerry Archaeological Magazine, Vol. 1, No. 2 (Apr., 1909), pp. 84-94

Stable URL: http://www.jstor.org/stable/30059594

\section{Accessed: 20-06-2016 16:13 UTC}

Your use of the JSTOR archive indicates your acceptance of the Terms \& Conditions of Use, available at

http://about.jstor.org/terms

JSTOR is a not-for-profit service that helps scholars, researchers, and students discover, use, and build upon a wide range of content in a trusted digital archive. We use information technology and tools to increase productivity and facilitate new forms of scholarship. For more information about JSTOR, please contact support@jstor.org. 
(84)
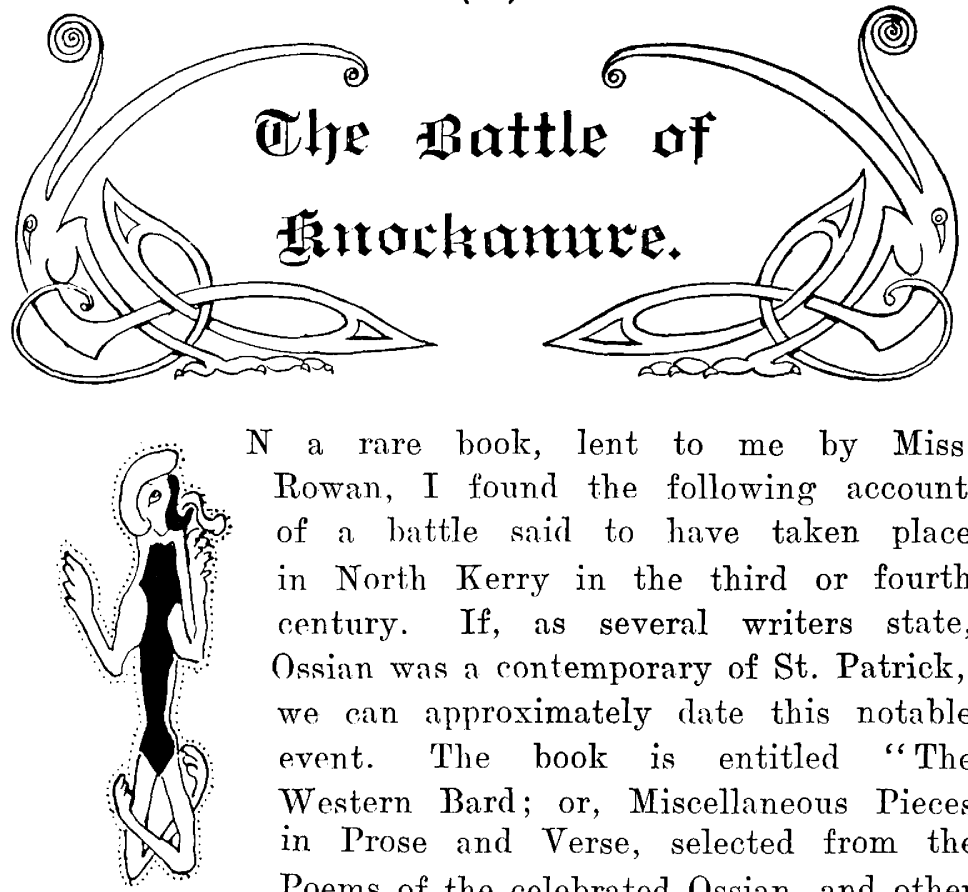

$\mathrm{N}$ a rare book, lent to me by Miss Rowan, I found the following account of a battle said to have taken place in North Kerry in the third or fourth century. If, as several writers state, Ossian was a contemporary of St. Patrick, we can approximately date this notable event. The book is entitled "The Western Bard; or, Miscellaneous Pieces in Prose and Verse, selected from the Poems of the celebrated Ossian, and other Irish Manuscripts. Translated into English by Thomas de Stack, S.M."' Mr. Stack seems to have collected many wonderful tales, but I give only the introduction and the legend which is expressly stated to relate to Kerry. It will be noticed that the same name is differently rendered in different sentences-possibly copyist's mistakes-but as I am not learned enough to decide which is right, I give them as they appear in Mr. Stack's translation. It is extraordinary how all Irish writers of the early Christian period constantly allude to Greece, rather than any nearer country with which one might expect them to be better acquainted, and how many Greek words appear as ecclesiastical terms in Ireland. The only other country we hear much of from writers of this period is Egypt. I may mention that, according to Dr. Joyce, Knockanare "means The Hill of Slaughter," but "Knockanure: The Hill of Yew Trees." Knockanure, in Irraghticonnor, is about 
nine miles from the Shannon. The present village is some distance from the old church and hill which formerly bore the name. I give a photograph of them, which was kindly supplied by Mr. Gun-Mahony, of Kilmorna.

\section{HUSSEY.}

\section{THE BATTLE OF KNOCKANURE.}

“The learned Mr. O'Halloran, in his introduction to the history of Ireland, mentions that there was a book entitled "Agal na Seiniorye," or the Dialects of the Ancients, somewhere preserved in the county of Kerry or Limerick. This book was formerly in the possession of one Eagan O'Rahilly, a celebrated poet and antiquarian, who died in the eighteenth century. It set forth that the celebrated Ossian, the son of Fion, and father of Oscar, lived at the time that St. Patrick preached the Gospel in this Kingdom, and that he owed his longevity to the following wonderful circumstances:-Being one day hunting, he accidentally, in pursuing a deer, separated himself from the rest of the champions, and met with a young woman of the most exquisite beauty, in a romantic glen. On viewing her lovely features, being of an amorous disposition, he was suddenly smitten with her charms; she in like manner, viewing the Irish hero's comely shape, well-proportioned limbs, and manly appearance, became enamoured of him, and requested of him to go with her to her own country, where it was in her power to bestow upon him immortality and perpetual youth; upon which he consented. She took him through a subterranean passage to her own country, called Tiernanoag, or the country of the immortals, which is described to be superior to the Valley of Temper or the Elysian fields of the ancients. In this country the brave Ossian lived for more than two centuries, enjoying every rural pleasure that could be imagined, not thinking of his country or companions during that long period of time. At last, awaking from this pleasing lethargy, and thinking 
of his kindred in Ireland, he intimated to this fair creature that he thought it high time to return to his native country, and pay a visit to his father, the renowned Fion, and the other champions. On hearing these words, his wife, who was an enchantress, smiled, and said it was no more than folly for him to think of leaving the country he was in, where he enjoyed everlasting youth and every other felicity, and that there were no traces of Fion nor of the Fionaeirion to be found or met with in Ireland, being all dead for a series of years. She then asked him how long did he think he lived in the country of the Immortals. He replied, "About a few months." " Why," she said, "you are an inhabitant of this country for more than two hundred years, but in consequence of enjoying such a round of uninterrupted felicity you did not feel the time glide away, so much is this country under the immediate protection of the Gods." Ossian not giving credit to what she averred, replied: "Most amiable and worthy lady, all the pleasures that the universe can afford will not henceforth prevent me from this determination of seeing $\mathrm{my}$ father and the rest of my former brethren in arms, and that dear Emerald Isle which gave me birth." “Since you are so positive," said she, "you may act as you please; and go and accoutre the white steed you will find in such a particular stable, then mount him, and he will take you, free from any danger, to Ireland; but, my dear, I counsel you still further not to dismount on any account while you remain in that country, for if you do you can never see this country more, as the steed will vanish from your sight and you will grow a miserable, decrepid old man and feel the miseries and infirmities peculiar to old age, and will be a real object of pity.' Whereupon Ossian, taking his leave of this lovely maid, did as he was directed, and pursuing his journey through unknown regions, safely arrived in his own country, where he was very much surprised at 
the degeneracy and small stature of the inhabitants, and seeing some persons driving horses which were laden with corn to the next town to sell, and one of the sacks accidentally falling, three or four of the men strove to lift up the sack upon the horse's back, whereupon Ossian coming up, was astonished at their weakness, seeing that four men could not lift up a small sack, and asked them in what part of the country did Fion McCuval and his champions reside. The peasants replied that no such people then existed as the Fianaeirion, but that they were informed by tradition that such heroes existed some centuries before. Then Ossian alighting from his steed, easily lifted up the sack, and as soon as his feet touched Irish ground he was immediately transformed into a feeble, ghastly, grey, old man, quite helpless, and in that state was taken to the house of St. Patrick, between whom began a most pleasing dialogue in Irish verse, Ossian giving a most poetical and elegant account of the valorous exploits performed by each hero, and particularly by the renowned Oscar. In this dialogue Ossian gave a particular account of a most bloody battle fought at Knockanore, in the barony of Irraghticonnor, in the county of Kerry, in the third century, which happened in the following manner :-

One day as Fion and his seven battalions of Irish Militia were performing several feats of military exercises on the declivity of this hill, near the brink of that lordly and limpid river called the Shannon, Fion's Druid took a careful view of the firmament, and immediately consulted his art of divination, by which he found that some impending danger was approaching, and apprised Fion thereof, requiring of him to send a watchman to every coast in Ireland, as usual, to give intelligence of the enemy, and to make the battalions prepare, as they should soon have occasion to fight a tremendous and bloody battle, and pointed out to Fion the bloody signs he saw 
in the firmament, by his conjurations, which plainly evinced the impending danger. Fion, chewing his thumb from the bone to the marrow, as was his custom, found that the Druid had predicted right, and according to his directions, sent watchmen to the respective harbours of Ireland.

They were not long in this dilemma, when they beheld a most beautiful woman approaching them arrayed in rich habiliments, having a noble air and graceful deportment; and she requested of the first man she met to direct her to where Fion, the King of the Fians, was, and to introduce her to his majesty. She was immediately ushered into his presence, and he no sooner beheld this incomparable beauty, than he welcomed her, at the same time inquiring her business, from whence she came, or of what region was she an inhabitant. "Most noble champion," said she, "I am the only daughter of the King of Greece, who promised me in marriage to a hero named Talemactroen, who is a renowned champion, celebrated for his magnanimous deeds, yet I disdainfully rejected him; the reason why I disliked him was his being monstrously deformed in body by enchantment, being of a gigantic stature and his complexion and skin as black as any beetle, and having the ears, head, and tail of a cat. Being resolved in mind to suffer the greatest punishment and even death itself sooner than become his wife, I have retired in disguise from my father's court, and in this manner roamed from one country to another until I travelled the known world, hoping to find a champion to espouse my cause and protect me from this hero, but all in vain as no emperor or king to whom I applied, would engage in my quarrel, but flatly denied me, as Tale is highly celebrated throughout the world for the mighty achievements he has performed in several kingdoms at different times. It appears that his name is a terror to them. This, O illustrious Chief, is my mournful story, 
and now I apply to you, as my last refuge and consolation, hoping and expecting that as you have at your command a valorous band of renowned Irish heroes, you will be the protector of a helpless young maiden, the daughter of a King."

This speech being ended, made a great impression on Fion. He asked her name. She answered: "Niavnovyraliach."

" Madam," replied Fion, "I give you protection, and vow by my honour and the arms of chiralry, to espouse your cause with all my heart; it is my rule never to refuse protection or friendship to the distressed, and though you describe this Tale to be so great a hero, I shall be surprised if I find not a match for him in single combat."

After the princess had returned him her unfeigned thanks for his courtesy, Fion introduced her to his lovely and amiable consort, whose name was Greney, who sumptuously entertained her in her hospitable palace. In the course of the day Fion perceived at a distance something like a large cloud approaching him, and as it drew near it totally eclipsed that part of the horizon. He then perceived the hero emerging from it in the same form that the princess described, completely armed from head to foot, with a shining keen-cutting sword in his hand of uncommon size. Coming up to where Fion stood he asked him if he were Fion McCuval, the commander of the Fianaeirion. Fion replied in the affirmative. Tale then asked if he had granted protection to Niavnoveraliach the daughter of the King of Greece. Fion replied that he had never refused to protect the helpless.

"Well," said Tale, "deliver back this princess to me, or send me two hundred of your best men to fight instantly."

Whereupon Fion ordered 200 brave warriors to put on their armour and attack him, but the spirited valiant champion slew them all in a short time, and requested 
THE BATTLE OF KNOCK.ANURE.

double the number to be sent the next day, which he in like manner put to the sword, and continued to do so for four days, slaughtering and massacring the flower of Fion's men, in such a manner that he terrified the whole army. When the brave Oscar saw such a defection of the Irish troops, in consequence of Tale making such a havoc among them, he became highly enraged, and armed himself immediately, taking his never-failing sword in his hand, came to the battle, and challenged Tale to fight the following morning. This the other willingly accepted. Early next morning these two distinguished heroes entered the lists, and encountered each other in such a manner that both their shields emitted flashes of fire and seemed all in a flame, from the force of the tremendous blows they gave each other, and their powerful, brave, vigorous, warlike and astonishing combat continued for the space of five days, until the valiant Oscar, getting into better spirits, and seeing the honour of his country at stake, valiantly beheaded him. As soon as he expired, the enchantment forsook him, and he appeared the most beautiful corpse that ever mortal man beheld. When the Grecian princess beheld the dead hero's incomparable beauty, she reflected on his magnanimous exploits, and beholding the number of warriors that were untimely slain on her account, she became so overwhelmed with woe that she gave a heart-rending sigh and instantly died.

When Margach, of the Green Sword, the brother of Tale, was informed in Greece of his death, he vowed revenge, and shortly after, with his two valiant sons, and a formidable train of champions, he set sail for Ireland, landing on the spot where Fion was encamped, and signifying that they came in a hostile manner, Margach came up to Fion, and without much ceremony demanded 500 of his best men, which he would fight with his single arm. The following morning Fion obeyed his order, and Margach encountered them so valiantly that they all fell 
by his sword in one day; and so he went on for seven days, until by the prowess of his single arm alone he much thinned the Irish army, which when the noble and renowned Oscar had seen, he came to his grandfather, Fion, and earnestly requested leave of him to fight this scourge of his country; but Fion would by no means grant him leave, alleging that Oscar was his shield and protector, and that if he were slain in the encounter the Irish warriors would be totally annihilated. Then Fion, in a desponding manner, went to each of his chief champions, requesting that some one or other of them would fight Margach in single combat; but each champion refused to fight him singly, saying that they would collectively encounter him and his champions. The most diminutive commander of a battalion, whose name was Ceenleigh, told Fion that he would encounter this foreign hero, in a spirited manner, which could not but make Fion laugh, to think that the bravest champions in the world refused to fight Margach, and that Ceenleigh voluntarily offered to encounter him. Whereupon the next day he came to the field of battle; but when Margarch saw him approaching, flourishing his trusty sword, he asked if this champion was to be his antagonist. Fion replied that he was. "I will not fight nor stain my sword with the blood of such a diminutive creature," said Margach, "but will send his equal to encounter him," which he accordingly did, and both heroes valiantly encountered each other, until at last Ceenleigh, watching his opportunity, gave the other such a powerful stroke that he severed his head from his body.

When the Irish army saw the Grecian slain they gave three jovial cheers. This enraged Margach to such a degree that he swore that if Fion did not find a champion the following morning, who would fight him in single combat, he would slay all his men except Fion and his son Hugh the Small, whom he would carry captive to 
his own country, to grace his conquest. When Oscar was informed of the infidel's menace, he immediately challenged him to single combat, and began to arm himself by placing on his head his plumed helmet. He put on his coat of mail, and adorned his breast with a refulgent cuirass, and put on his shield wrought of Lydian steel, embossed with gold, on which was emblazoned the genius of Erin, emerging like another Venice from the bosom of the Atlantic Ocean, attended by the mermaids and several other sea nymphs, and Thetis, Amphitrite, and Triton calming the waves and conveying her on shore, as the protectress of the Ogygian Isle, accompanied by the music of the sirens. He put on his shoulders a radiant baldrick or belt, from which hung his sharp, shining sword, wrought of different metals, his legs being cased in greaves of resplendent hue, bound with gold buckles; and thus accoutred he rushed towards the field of battle, a strong, valiant, magnanimous hero, nimble, active and vigorous, with a most pleasing and engaging countenance, and manly appearance. Then, being fired with the greatest rage that Margach should cast so gross a reflection on his country, he challenged him to fight, which Margach accepted with the like eagerness, and the two heroes encountered each other like two fierce lions or two furious bulls, in such a manner that with the violent fury of their weighty blows the sea and river Shannon seemed ruffled and agitated, and the ground on which they fought shook in such a manner that it resembled an earthquake. Thus they continued, each giving and receiving many grievous blows, until night put an end to the engagement for that time. When the heroes rested and sat together, Margach spoke, addressing Oscar after the following manner:

" Oscar, thou art one of the bravest and most manly champions that I ever encountered, but be assured that I will surely vanquish thee, and bear away thy head, as 
every part of me is invulnerable and no weapon can ever wound me, nor can I ever be consumed by fire."

"Perhaps it may be as thou sayest," replied the Irish champion, "but I shall be much surprised if before to-morrow evening my sword do not enter thy flesh." Upon which the heroes departed each to his place of repose.

Next morning, as soon as Aurora ushered in the day, the heroes resumed this memorable conflict, and before noon Margach was deeply wounded by the valiant Oscar, and each from the other received many dangerous wounds. In this awful and tremendous combat did these heroes continue, incessantly cutting and marring each other, for the long period of ten days, till on the tenth day Margach cried out to Oscar in a feeble voice, imploring him to grant an hour or two to rest, but Oscar refused, saying he was determined not to cease from his combat until one of them should fall. At last Oscar valiantly beheaded Margach. Such was the end of Margach in spite of all his boasting that no mortal was able to conquer him.

Next day, when Margach's two sons, Ciardan and Leagan, found that their father was slain, each in his turn challenged our renowned hero, who undauntedly fought them, though he was grievously wounded, and made both of them share the same fate as their father.

When Aile the Fair, wife of Margach, thought it too long since she had heard anything of her husband's expedition, she prepared a ship and set sail for Ireland. On arriving, she came to the field of battle, and inquired of Fion, who informed her that her husband and two sons were slain in single combat, and he showed her the spot where they had died. When she arrived there, most dolefully bewailing their loss, she composed an extempore poem on their valorous achievements, which sho plaintively recited in a most melodious voice, after the manner of her country, and boldly asserted that her husband and two sons were treacherously slain. Fion answered that the heroes of Ireland ever scorned to take the least advantage of any champion, and he assured her 
that her heroes got fair play and were fairly vanquished, not by himself, but by the valiant Oscar, in single combat; that they were an honour to their country, as they behaved in a most noble and courageous manner; and "Be it known to you, fair lady," said he, "that Irish champions are too noble-minded to use any method derogatory to the laws of chivalry or true heroism to vanquish their opponents." Aile would not believe his words, and ordered the remainder of her forces to attack the Irish army; but the Irish champions behaved so valiantly that in a few hours the forces of Aile were totally routed and all slain except three, whom they humanely spared to convey Aile to her own country. And thus ended this memorable battle, from which the hill on which it was fought was called Knuckander, from the number of heroes who were slain in this fierce battle, and now by corruption it is called Knuckanore."

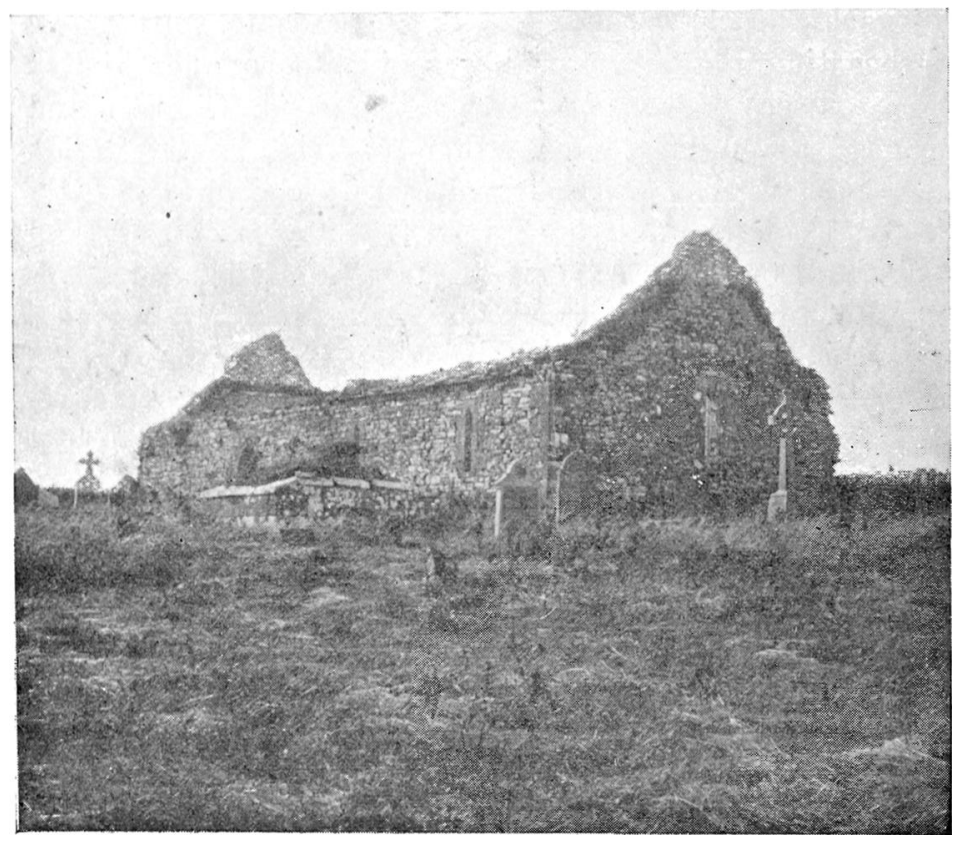

KNOCKANURE RUINED CHURCH.

By Dr. Frederick Vicars 